\title{
TRENDS IN CHANGES OF OUTCOMES AND INVESTMENT OUTLAYS IN ENVIRONMENTAL PROTECTION AND WATER MANAGEMENT IN SPATIAL TERMS IN POLAND
}

\author{
Barbara Golebiewska" PhD hab., prof. WULS \\ ${ }^{1}$ Warsaw University of Life Sciences, Faculty of Economic Sciences, Poland
}

\begin{abstract}
Increased use of resources, plundering economy, and intensification of environmental pollution raises continuously more problems. The question arises: in what way could such a phenomenon be prevented. After Poland's accession to the EU, there has been significant progress in environmental protection. It was caused, among other factors, by an increase in expenditures on fixed assets for environmental protection.

The objective of the study is to assess activities in the field of wastewater management and water protection in financing investments on fixed assets. It was discovered that spatially these expenditures were remarkably diverse. Significant differences in outlays also occurred between rural and urban areas.
\end{abstract}

Key words: environmental protection, investment, expenditures.

JEL code: Q5, Q50

\section{Introduction}

Increasing use of environmental resources by population creates many problems that not only deteriorate environmental value but also may be a threat to the society's safety and well-being. Environmental problems deriving from intense utilization of materials regard both environment and society (Golebiewska B. et. al., 2016). The must for counteracting these problems causes the demand for measuring the influence and impact of human actions (new technologies, techniques) on environment. However, it becomes more difficult because, as Simmons (1979) stated in the $70 \mathrm{~s}$, it is not wise to evaluate the impact of human on environment, because the loss of environmental values cannot be expressed in monetary values. It is still relevant today, though increasingly more often there are attempts of assessing those values (e.g. Wilkin J., 2010; Brelik A., 2013; Pajewski T., 2016), even though these are priceless goods (non-marketable goods). Zylicz (2007) brings attention to that, pointing that a few decades ago economy was helpless in evaluating non-marketable goods. It is worth discussing how accurate those assessments are in comparison to the real value of public goods. Using those measures may be helpful though in evaluating amends (fees) for generating devastation to the environment.

In recent years in Poland, especially after joining the EU, a significant advance has been made in environmental protection. The main cause of that was the need to meet numerous obligations against the EU. Hence there is a need to increase environmental expenditure. According to Wicki and Wicka (2016), Golebiewski, Rakowska (2017) in order to introduce new solutions, financial resources are needed for this purpose, which are not always sufficient. In the last decade, significant growth in the outlays on fixed assets for environmental protection has been made. Amongst those outlays, there are expenditures on atmospheric air and climate protection, wastewater management and water conservation, waste management, preservation of soil and restoring its agricultural value, protection of underground and surface water, reduction in noise and vibration, biodiversity and landscape conservation and protection against ionizing radiation (Environment 2016).

Research and analysis in the field of environmental protection expenditures are increasingly undertaken by many authors (including Famielec J. (ed.), 2005; Koziol J., 2005; Poskrobko B., 2007; Bujanowicz-Haras B., 2009; Fura B., 2010; Golebiewska B., Slusarz G., 2014). The sources and directions of investment are being assessed. Economic aspects of environmental protection are the subject of many studies concerning, among others, development of agriculture in protected 
areas (Boltromiuk A., 2003), determinants of eco-development in protected areas (Poplawski L., 2009), or analysis of Natura 2000 protected areas (Klodzinski M., 2012). The aim of the study is to assess environmental protection measures in the field of sewage management and water protection in terms of financing investments in fixed assets used for this protection. The investments related to wastewater management and water protection include equipment for the disposal and treatment of industrial and municipal wastewater, rainwater (sewage) and contaminated mine water discharged directly into surface waters and into the ground. These include mainly sewage treatment plants or their elements in accordance with the purification technology (mechanical, chemical, biological and increased biogenic removal), also include individual household sewage treatment plants and investments related to the preliminary sewage treatment, devices for the economic use of sewage, for the utilization, collection and transport of waters The scope of data also includes construction of a sanitary sewage system discharging sewage and rainwater, equipment for processing and management of sludge from sewage treatment plants, circulating water supply systems, safeguards against penetration to rivers, seas and other water reservoirs pollutants arising in water transport, creation of protection zones for sources and water intakes (Environment, 2016). Expenditures for fixed assets concerning sewage management and water protection have been selected for the research, since they were the main direction of spending funds for environmental protection in Poland (Figure 1). As indicated also in the Guidance on wastewater management in the context of the implementation of the national municipal wastewater treatment program (Poradnik ..., 2010), Council Directive 91/271/EEC concerning urban wastewater treatment is one of the most expensive and difficult to implement EU legal acts. At the same time, it plays a fundamental role in the management of municipal sewage and the protection of the aquatic environment, including surface waters to which they are discharged. Therefore, this issue and its implementation can be considered as one of the main problems in the field of environmental protection.

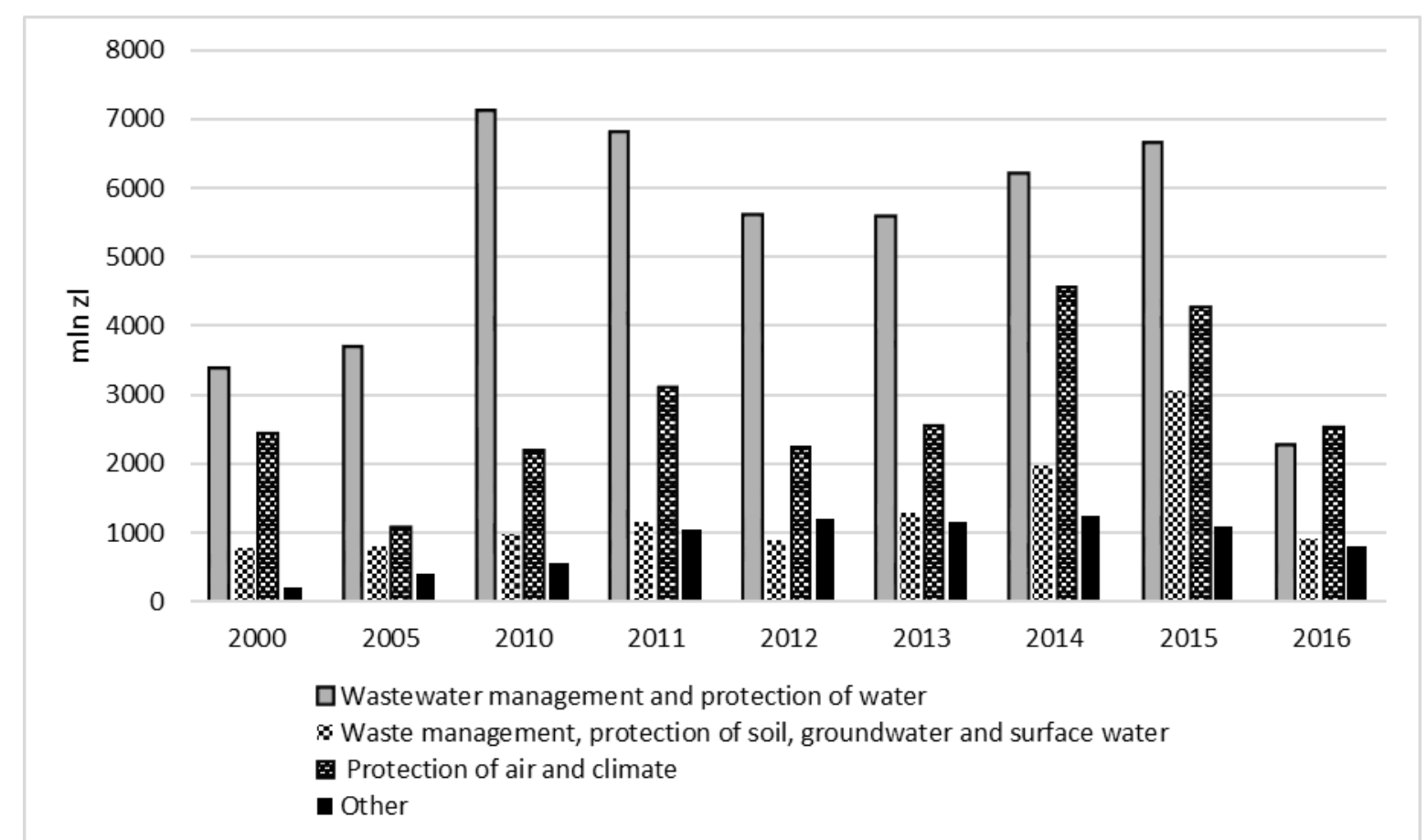

Source: Environment 2016. Notatka informacyjna GUS, 2017, https://stat.gov.pl/files/gfx/ portalinformacyjny/pl/defaultaktualnosci/5484/4/6/1/naklady_na_srodki_trwale_sluzace_ochronie_srodowiska _i_gospodarce_wodnej_w_polsce_w_2016.pdf, access 21.01.2018

Fig. 1. Outlays on fixed assets for environmental protection by investment directions 


\section{Research methodology}

Information on expenditure of fixed assets for environmental protection and their material effects since 1999 is presented in accordance with the Polish Statistical Classification on Activities and Equipment Related to Environmental Protection introduced by the Regulation of the Council of Ministers of March 2, 1999 (Dz.U. 1999 nr 25 poz. 218). These documents contain information on both global, regional and local problems, including waste, sewage, water and soil protection, noise reduction and biodiversity and landscape conservation. In Poland, there is considerable spatial differentiation in the situation of agricultural production. Among others, Franc-Dabrowska (2013) draws attention to this. This also applies to investments in environmental protection. This is related, to the specificity of regions or smaller (local) territorial units that have an impact on the pace and directions of both economic and social development. The study analyses the expenditures in spatial layout in Poland by voivodships. Data pointing to the differences between urban and rural areas have been used as well.

In urban areas, due to greater population, environmental problems are more noticeable. Large cities generate a very high demand for resources and "produce" more waste, or sewage. For this reason, they may require higher investment outlays for devices to prevent ecological instability.

Selected research tasks:

- displaying the level of outlays for wastewater management and water protection in entire country of Poland and in separate voivodships;

- determining of the number of residents using sewage treatment plants, as well as individual treatment plants, mainly in rural areas. The following analyses were used: GUS (Central Statistical Office) data in the field of environmental protection, information from the Chief Inspectorate for Environmental Protection, data from the Local Data Bank, information published by the Ministry of the Environment, the National Water Management Board and available literature on the subject.

\section{Research results and discussion Changes in the level of expenditures on wastewater management and water protection}

High priority in environmental protection has been given to restoring water purity. Adapted to the requirements of EU directives, the National Programme for Municipal Waste Water Treatment (NPMWWT) was supposed to equip all agglomerations above 2 thousand residents in collective sewage systems and municipal wastewater treatment plants by 2015. Pre-accession conversations negotiated adaptive transitional periods for the introduction of the above-mentioned regulations by the end of 2015. In the years 2000-2015, 851 municipal wastewater treatment plants were created (Environment, 2016). However, the assumptions were not accomplished, and the document has already been updated fifth time. It assumes creating in 2016-2021 116 new wastewater treatment plants and other investments on 1010 wastewater treatment plants (Biuletyn ..., 2017). The reasons for many delays, according to data from municipalities reports, are lengthy administrative and preparatory procedures for investments, long-term tendering procedures resulting from public procurement regulations, lengthy procedures for preparing and signing memoranda for co-financing projects from EU funds, problems related to land ownership, or also the lack of financial resources for implementation (Sprawozdanie ..., 2014). 
In Poland, in the years 2003-2016, there were significant differences in expenditure on wastewater management and water protection. This can be observed while comparing the values calculated per capita (Figure 2).

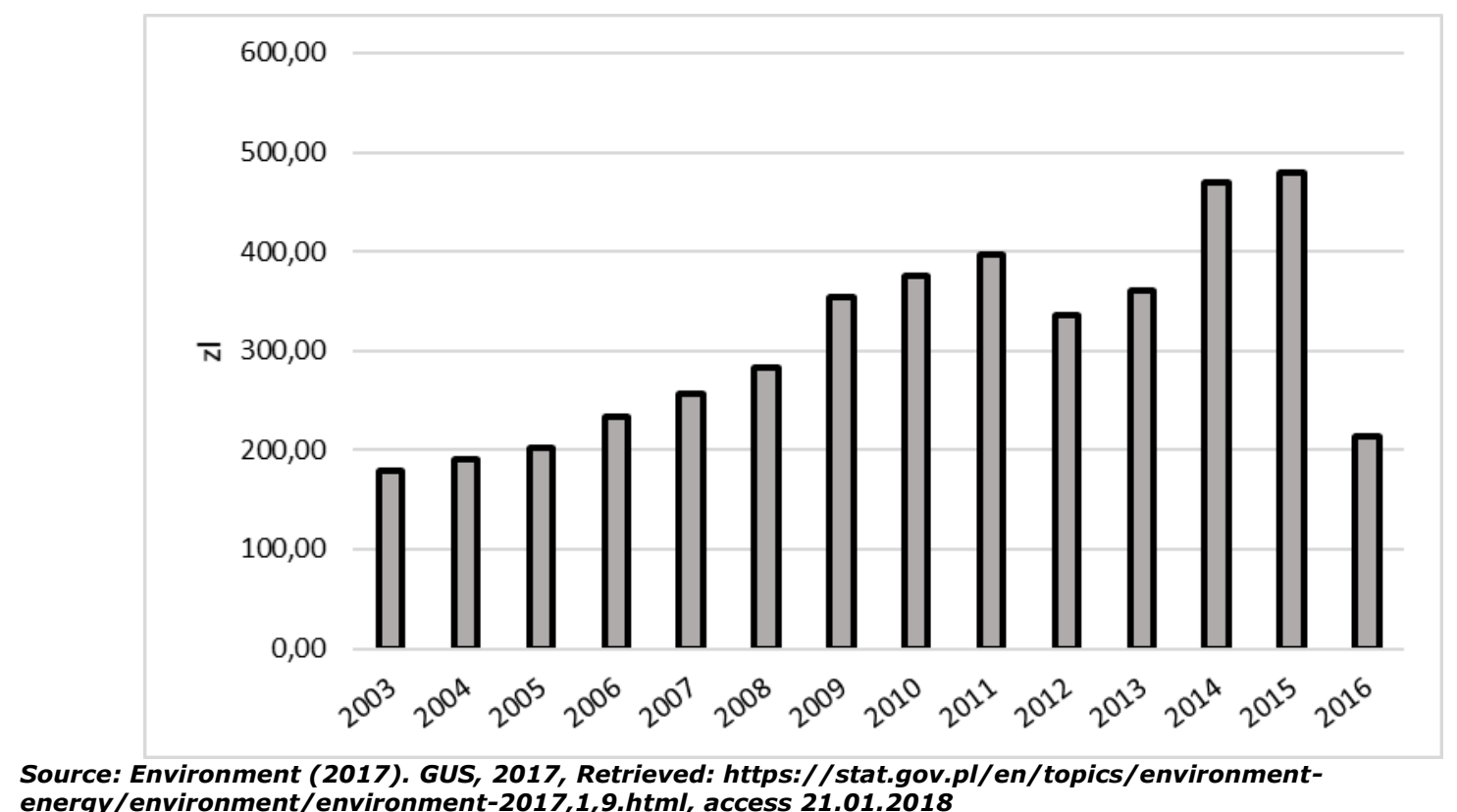
energy/environment/environment-2017,1,9.html, access 21.01.2018

Fig. 2. Outlays on fixed assets for environmental protection and water management per capita

Since 2004, slow but steady growth was observed in environmental protection expenditures, due to utilisation of EU funds for co-financing investment projects. The situation lasted until 2011. In 2012-2013, expenditures became lower to grow again in 2014-2015. In 2016, expenditures dropped down dramatically, it might have been caused by finalising many investments financed from EU funds for the years 2007-2013 and due to the fact that since 2016, the funds for 20142020 have not yet been completely utilised. Data in spatial terms, presented in Figure 3, point to the highest outlays in Slaskie and Mazowieckie voivodeship in the analysed period. High expenditures also occurred in Wielkopolska, Dolny Slask and Malopolska. It was caused, among other factors, due to occurrence of large urban areas in these regions, in which investments are more common than in the rural areas. 


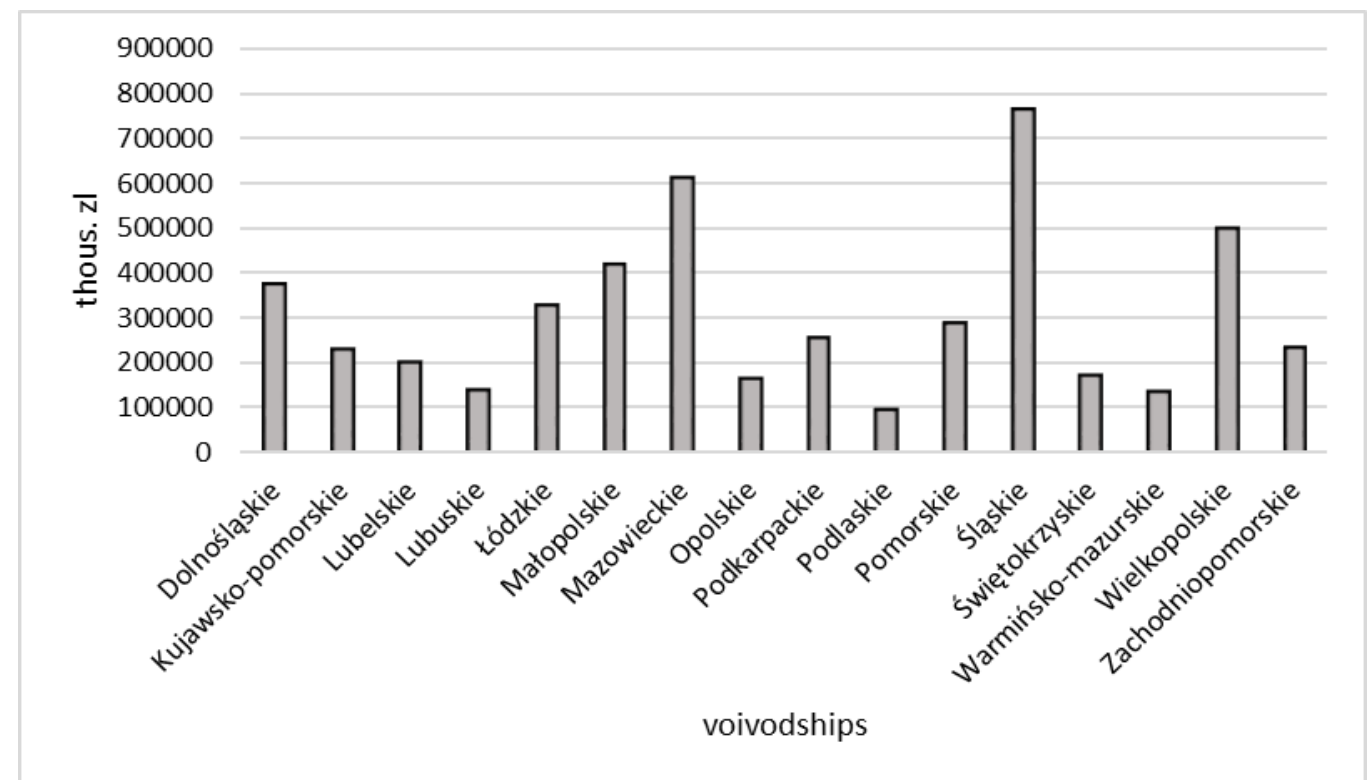

Source: Environment (2017). GUS, 2017, Retrieved: https://stat.gov.pl/en/topics/environmentenergy/environment/environment-2017,1,9.html, access 21.01.2018

Fig. 3. Expenditure on the wastewater economy on average in the years 2002-2016 by voivodships

Determination of demand for investments in wastewater management requires determining existing needs. Because of the lack of information about the number of required investments, the ratio of people using sewage treatment plants to the number of citizens of voivodeship was established. This information allows identifying needs for further investments. Because of large contrast in the amount of people using sewage treatment plants between rural and urban areas, analysis also included such spectrum (Figure 4).

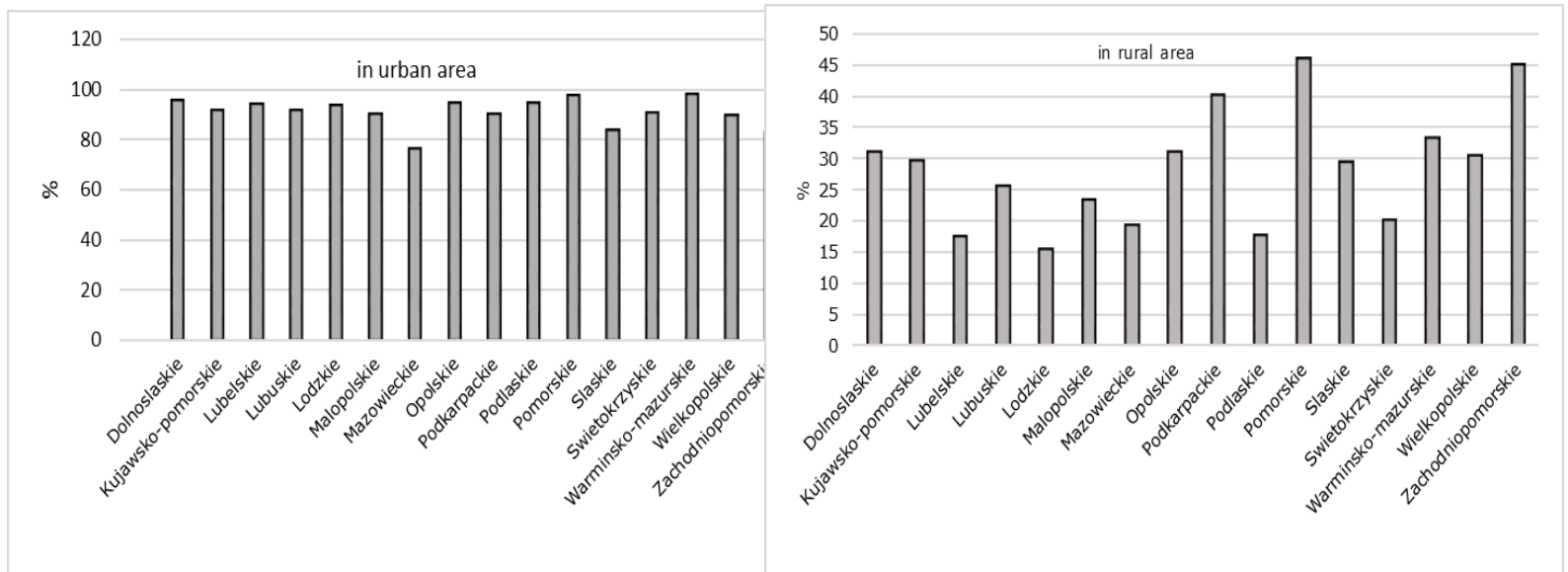

Source: author's calculation based on Local Data Bank. Retrieved: bdl.stat.gov.pl/BDL/metadane/podgrupy/305 Access: 11.01.2018

Fig. 4. Average share of people using sewage treatment plants in the years 2002-2016 by voivodships

The data presented indicate that in the cities the lowest share of population, whose household is connected to the sewage system, was the Mazowieckie voivodeship (less than $80 \%$ ). Rural areas generally have close to half of that number of residents using the connection to the sewage system. The largest share was held by the Pomorskie and Zachodniopomorskie voivodships, although this share was still less than $50 \%$. This indicates how much work still needs to be done regarding wastewater treatment plants in rural areas. Analysing changes in the scope of growth or 
decrease in the share of urban and rural residents using sewage treatment plants, it should be noted that since the beginning of the twenty-first century there have been major changes in rural areas (Figure 5). These changes ranged from $10 \%$ (Podlaskie voivodship) to even more than $40 \%$ (Opole voivodship). This indicates high demand and existing shortages in rural areas in the scope of existing sewage treatment plants.

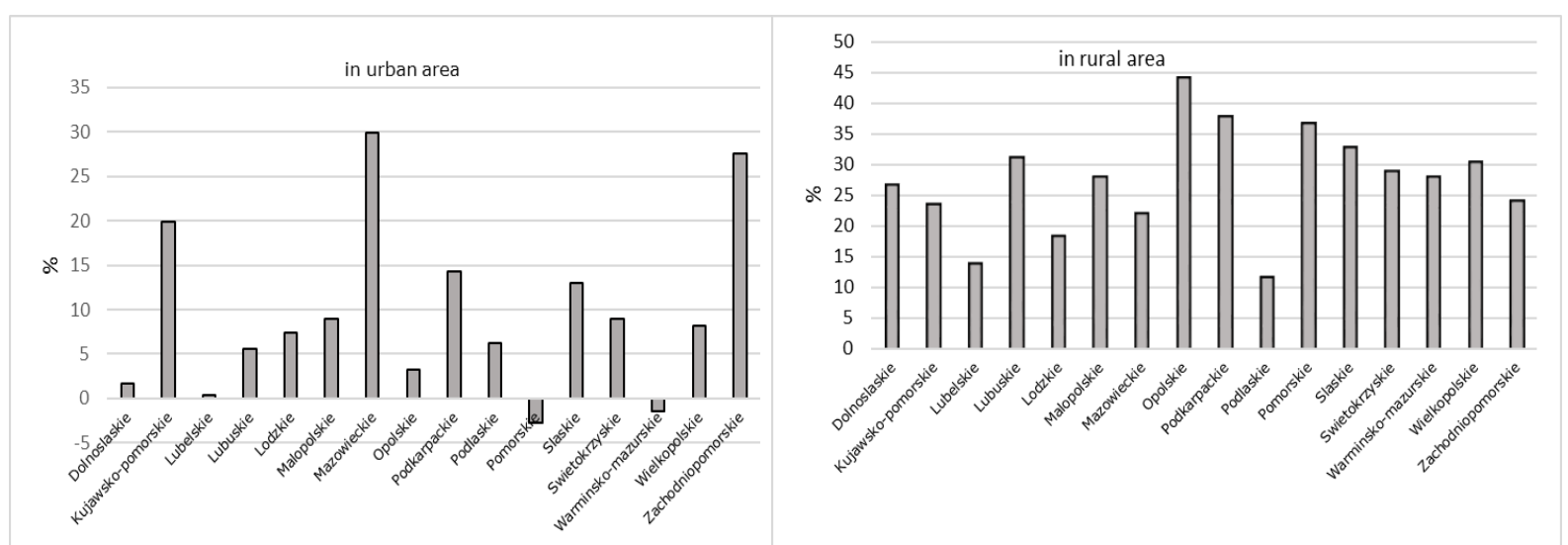

Source: author's calculation based on Local Data Bank. Retrieved: /bdl.stat.gov.pl/BDL/metadane /podgrupy/305, Access: 11.01.2018

Fig. 5. Changes in the share of population using sewage treatment plants in the total population in cities and in rural areas in the years 2002-2016 (\%)

In cities, these changes were not so large, which is due to the large number of existing treatment plants. However, the Mazowieckie and Zachodniopomorskie voivodeships were also characterized by a significant increase in the number of residents using the treatment plant. From the presented results it could be concluded that the situation in rural areas is still unfavourable. Although it should also be considered that there are many individual wastewater treatment plants in the countryside (Figure 6).

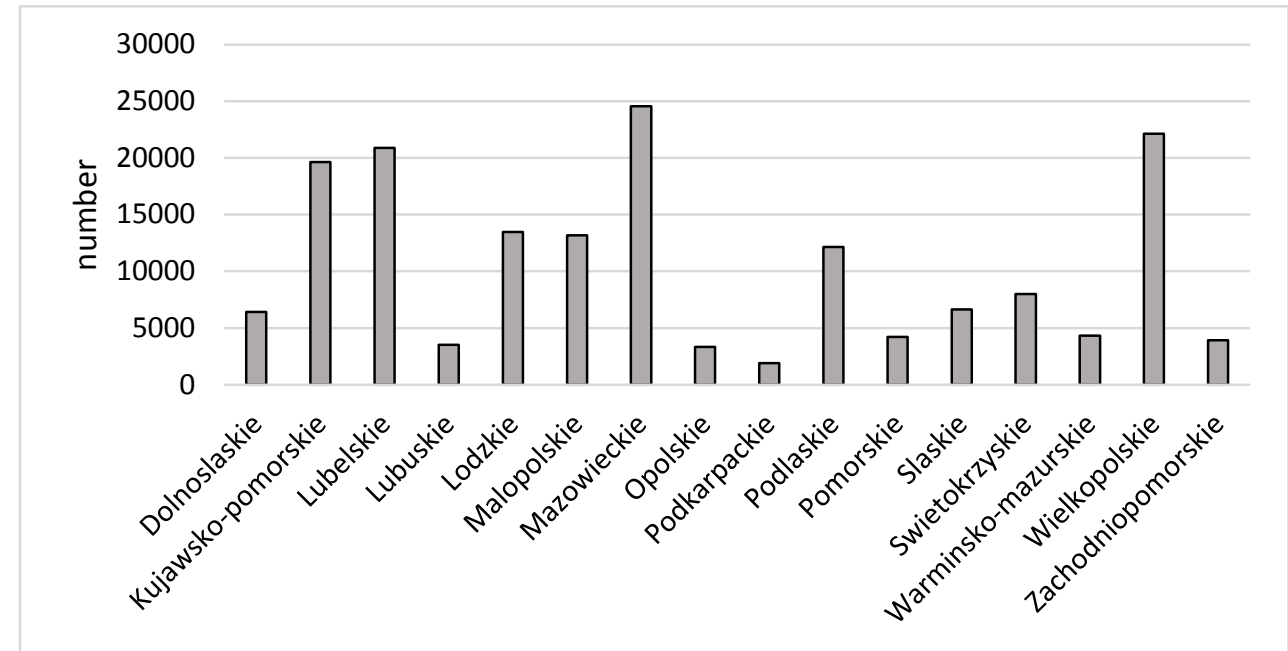

Source: author's calculation based on Local Data Bank. Retrieved: /bdl.stat.gov.pl/BDL/metadane /podgrupy/305, Access: 11.01.2018

Fig. 6. Individual rural wastewater treatment plants commissioned for use in the years 2002-2016 (pcs)

In the years 2003-2016, the largest number of such sewage treatment plants was established in Mazowsze and Wielkopolska. A considerable number of home treatment plants also distinguished the Lubelskie and Kujawsko-Pomorskie Voivodeships. The number of sewage treatment plants was 
not always associated with an increase in outlays. Data presented in Figure 7 indicate that the highest expenditures were incurred in the Kujawsko-Pomorskie Voivodeship and then Mazowieckie.

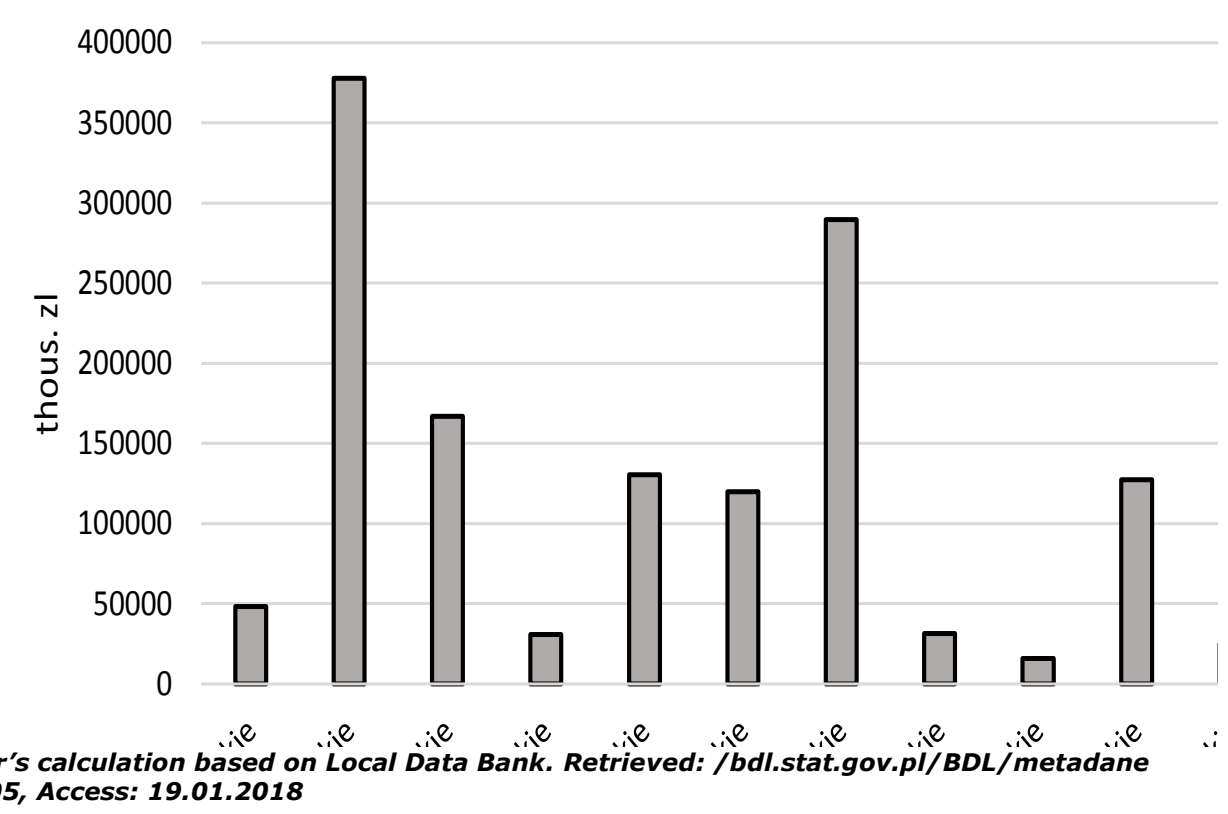

/podgrupy/305, Access: 19.01.2018

Fig. 7. Investment expenditures for individual rural wastewater treatment plants in the years 2003-2016

In Wielkopolska, manyf sewage treatment plants were also built, while expenditures were lower than, for example, in Podlaskie, where despite higher expenditures than in the Wielkopolskie voivodship, less sewage treatment plants were created. This points to a differentiation in the size, efficiency or innovation of the treatment plants being constructed.

\section{Conclusion}

Wastewater management and water protection in Poland is one of the main directions of spending expenditure on fixed assets in the field of environmental protection. In the case of sewage management and water protection in 2016, around $77 \%$ were invested in the construction of a sewerage network and $20 \%$ for wastewater treatment.

It was found that there is a significant variation in the expenditures incurred between the cities and the rural areas. In cities, due to greater population, environmental problems are more noticeable. Hence, big cities generate more rubbish, waste or sewage. The share of people using wastewater treatment plants in rural areas is much lower than in cities, although in the case of villages private sewage treatment plants need to be considered. Therefore, there is still a need to contribute higher expenditure on wastewater management and water protection in rural areas. In addition to financial resources, attention should be turned to other reasons for many shortcomings and delays in the implementation of investments. The main ones, among others, are chronic administrative procedures and preparatory procedures for investments or long-term tendering procedures.

After Poland's accession to the EU, there has been significant progress in environmental protection, including limiting the dependence of economic growth on environmental pressures. Further actions in environmental protection expenditures, including wastewater management and water protection, are a priority in the process of implementing the principles of pro-environmental activities in economic development. Membership in the EU requires the implementation of many 
obligations related to maintaining requirements in environmental protection, and in this respect a high priority has been given to restoring water purity and expenditure on wastewater management.

\section{Bibliography}

1. Biuletyn Informacji Publicznej Ministerstwa Srodowiska 2017. Krajowy program oczyszczania sciekow komunalnych (Bulletin Public Information of the Ministry of the Environment. National Programme for Municipal Waste Water Treatment). Retrieved: http://www.kzgw.gov.pl/. Access: 14.01.2018.

2. Boltromiuk, A. (2003). Ekonomiczne aspekty funkcjonowania obszarow chronionych (Economic aspects of the functioning of protected areas). Wyd. Uniwersytetu Bialostockiego. p. 267. Bialystok.

3. Brelik, A. (2013). Dobra publiczne a zrownowazony rozwoj agroturystyki - w poszukiwaniu wskaznikow wyceny. (Public goods and sustainable development of agritourism - in search of valuation indicators). Materialy konferencyjne z IX kongresu PTE, Polskie Towarzystwo Ekonomiczne (Polish Economic Society) Retrieved: http://kongres.pte.pl/kongres/do-pobrania.html. Access: 18.12.2017.

4. Bujanowicz-Haras, B. (2009). Regionalne zroznicowanie nakladow inwestycyjnych na ochrone srodowiska w Polsce (Regional diversification of investment outlays for environmental protection in Poland). Ochrona Srodowiska i Zasobow Naturalnych (Environmental Protection and Natural Resources), no 41, pp. 355-361.

5. Dz.U. 1999 nr 25 poz. 218. (Journal of Laws No. 25, item 218), Rozporzadzenie Rady Ministrow z dnia 2 marca 1999 r. w sprawie Polskiej Klasyfikacji Statystycznej Dotyczącej Dzialalnosci i Urzadzen Zwiazanych z Ochrona Srodowiska.

6. Environment (2016). Notatka informacyjna GUS, 2017, Retrieved: https://stat.gov.pl/files/gfx/ portalinformacyjny/pl/defaultaktualnosci/5484/4/6/1/naklady_na_srodki_trwale_sluzace_ochronie_srodowis ka_i_gospodarce_wodnej_w_polsce_w_2016.pdf. Access 21.01.2018.

7. Environment (2017). Statistical Information and Elaborations. Central Statistical Office. Warszawa. p. 551.

8. Famielec, J. (ed.) (2005). System finansowania ochrony srodowiska w Polsce (The system of financing environmental protection in Poland), AE, Krakow.

9. Franc-Dabrowska, J. (2013). Regional Dversification of Financial Situation of Agricultural Enterprises in Poland. Earth Bioresources and Life Quality 2013, No 4.

10. Fura, B. (2010). Naklady inwestycyjne w ochronie srodowiska a realizacja zalozen rozwoju zrownowazonego (Capital Investments in Environmental Protection in View of the Accomplishment of the Sustainable Development Assumptions). Nierownosci spoleczne a wzrost gospodarczy, no 17, pp. 303-301. Retrieved: ur.edu.pl/pliki/Zeszyt17/23.pdf. Access: 31.01.2018.

11. Golebiewska, B., Chlebicka, A., Maciejczak, M. (2016). Rolnictwo a srodowisko. Bioroznorodnosc i innowacje srodowiskowe w rozwoju rolnictwa (Agriculture and the environment. Biodiversity and environmental innovations in agricultural development). Wyd. Wies Jutra. Warszawa. p. 123.

12. Golebiewska, B., Slusarz, G. (2014). Zroznicowanie nakladow na ochrone srodowiska na terenach wiejskich w ujeciu regionalnym w latach 2005-2012 (Diversification of Natural Protection Investments in Rural Areas in 2005-2015 (Regional Perspective). Zeszyty Naukowe SGGW w Warszawie. Ekonomika i Organizacja Gospodarki Zywnosciowej, no 107, pp. 93-102.

13. Golebiewski, J., Rakowska, J. (2017). Production and use of bioenergy in Poland in the context of the development of bioeconom. Proceedings of the International scientific conference Rural Development 2017, Bioeconomy challenges, pp. 274-280. http://doi.org/10.15544/RD.2017.195.

14. Grzebyk, B. (2010). Finansowanie ochrony srodowiska w Polsce (Financing environmental protection in Poland), Nierownosci Spoleczne a Wzrost Gospodarczy, z. 16, pp. 293-302.

15. Klodzinski, M., (2012). Barriers to Multifunctional Development of Rural Areas. Wies i Rolnictwo, nr 2, pp. 40-56.

16. Koziol, J. (2005). Polski system finansowania ochrony srodowiska naturalnego. Rocznik Zyrardowski 3, pp. 29-45. Retrieved: http://mazowsze.hist.pl/29/Rocznik_Zyrardowski/655/2005/23538/. Access: 31.01 .2018$.

17. Pajewski, T. (2016). The External Effects in Agriculture and Methods for Regulating. Journal of Agribusiness and Rural Development 2016, nr 2, pp. 375-383.

18. Poplawski, L. (2009). Uwarunkowania ekorozwoju gmin wiejskich na obszarach chronionych wojewodztwa swietokrzyskiego (Conditions of eco-development of rural communes in protected areas of the Swietokrzyskie voivodship). PWN. Warszawa. P. 367.

19. Poradnik dotyczacy gospodarki sciekowej w kontekscie wykonania krajowego programu oczyszczania sciekow komunalnych. (2010). Krajowy Zarzad Gospodarki Wodnej. Retrieved: www.kzgw.gov.pl/files/kposk/06-materialy/poradnik-KPOSK.doc. Access: 31.01.2018.

20. Poskrobko, B. (red.) (2007). Zarzadzanie srodowiskiem (Environmental management), PWE, p. 328, Warszawa.

21. Simmons, I.G. (1979). Ekologia zasobow naturalnych (The ecology of natural resources). PWN, Warszawa. P. 502.

22. Sprawozdanie z wykonania krajowego programu oczyszczania sciekow komunalnych w latach 2012-2013. (2014). (Report on the implementation of the national municipal wastewater treatment program in 20122013), Ministerstwo Srodowiska, p. 35. Warszawa.

23. Wicki, L., Wicka, A. (2016). Bio-Economy Sector in Poland and its Importance in the Economy. Economic Science for Rural Development, 41, 219-228. 
Proceedings of the 2018 International Conference "ECONOMIC SCIENCE FOR RURAL DEVELOPMENT" No 48

Jelgava, LLU ESAF, 911 May 2018, pp. 93-101

DOI 10.22616/ESRD.2018.073

24. Wilkin, J. (2010). Wielofunkcyjnosc rolnictwa (Multifunctionality of agriculture). Kierunki badan, podstawy metodologiczne i implikacje praktyczne, Warszawa, IRWiR PAN.

25.Zylicz, T. (2007). Wycena dobr nierynkowych (Valuation of non-marketable goods), Aura, Retrieved: http://coin.wne.uw.edu.pl/tzylicz/aura.html. Access 20.11.2017. 